\title{
House prices, consumption, and monetary policy: a financial accelerator approach
}

\author{
Kosuke Aoki* \\ James Proudman** \\ and \\ Gertjan Vlieghe
}
*_kosuke.aoki@crei.upf.es, CREI, Universitat Pompeu Fabra and CEPR.
**_james.proudman@bankofengland.co.uk, Conjunctural Assessment and Projections Division, Bank of England.
$\dagger \quad$ jan.vlieghe@bankofengland.co.uk, Monetary Assessment and Strategy Division, Bank of England, and London School of Economics.

We would like to thank Mark Gertler and Simon Gilchrist for invaluable suggestions and advice. We would also like to thank Peter Andrews, Larry Ball, Charles Bean, Chris Carroll, Roy Cromb, Spencer Dale, Emilio Fernandez-Corugedo, Jan Groen, Andrew Hauser, Anil Kashyap, Frederic Mishkin, Ed Nelson, and John Vickers, and conference participants at the Federal Reserve Bank of New York, the Bank of Japan, and the Bank of England for helpful comments. The views expressed here are those of the authors and do not necessarily reflect those of the Bank of England. An earlier version of this paper was entitled 'Houses as collateral: has the link between house prices and consumption in the UK changed?' and a non-technical version of it was published under the same title in the Federal Reserve Bank of New York Economic Policy Review.

Copies of working papers may be obtained from Publications Group, Bank of England, Threadneedle Street, London, EC2R 8AH; telephone 0207601 4030, fax 0207601 3298, e-mail mapublications@bankofengland.co.uk

Working papers are also available at www.bankofengland.co.uk/wp/index.html

The Bank of England's working paper series is externally refereed. 


\section{Contents}

$\begin{array}{ll}\text { Abstract } & 5\end{array}$

$\begin{array}{ll}\text { Summary } & 7\end{array}$

1 Introduction $\quad 9$

2 A brief description of the UK housing market 11

3 The effect of monetary policy on house prices: some VAR results 14

4 Modelling the household credit channel $\quad 15$

5 The model 20

6 Model simulations 26

7 Conclusion 31

Appendix 1: Complete log-linearised model 33

Appendix 2: Parameterisation 36

$\begin{array}{ll}\text { Appendix 3: Data sources } & 38\end{array}$

$\begin{array}{ll}\text { References } & 39\end{array}$ 


\begin{abstract}
There is a live debate about the role of house prices in the transmission mechanism of monetary policy. Do house prices merely reflect macroeconomic conditions, or are there important feedback effects from house prices to other economic variables? We consider a general equilibrium model where asymmetric information problems create frictions in credit markets used by households. In particular, we apply the financial accelerator mechanism of Bernanke, Gertler and Gilchrist to the household sector. In our economy, houses serve two purposes: they provide a stream of housing services to consumers and they serve as collateral to lower the agency costs related to borrowing. We show that under certain conditions this amplifies and propagates the effect of monetary policy shocks on housing investment, house prices and consumption. We also consider the effect of a structural change in credit markets that lowers the transaction costs of additional borrowing against housing equity. We show that such a change would increase the effect of monetary policy shocks on consumption, but would decrease the effect of monetary policy shocks on house prices and housing investment.
\end{abstract}

Key words: House prices, credit frictions, monetary policy, financial accelerator, consumption. JEL classification: E32, E50, R21. 


\section{Summary}

The Bank has a long-standing interest in the role of house prices in the transmission mechanism of monetary policy. Do house prices merely reflect macroeconomic conditions, or are there important feedback effects from house prices to other economic variables? There have been structural changes in the retail financial markets in the United Kingdom since the late 1980s. Following deregulation in the mortgage market, it has become easier and cheaper for consumers to borrow against housing collateral to finance consumption. What implications do these structural changes have for monetary policy?

In this paper, we model households' consumption and housing decisions taking account of the possible importance of credit frictions. Our hypothesis is that house prices play a role because housing is used as collateral to reduce the agency costs associated with borrowing to finance housing investment and consumption. Our motivation is based on three observations for the United Kingdom: (i) house prices and housing investment are strongly cyclical, which leads to substantial variation in households' collateral position over the business cycle; (ii) the amount of secured borrowing to finance consumption is closely related to this collateral position; (iii) the spread of mortgage rates over the risk-free interest rate varies with the collateral position of each household. These stylised facts suggest credit frictions and households' use of their housing equity as collateral may be important in understanding the relationship between interest rates, house prices, housing investment and consumption.

Our model applies a financial accelerator mechanism to the household sector. When house prices fall, households that are moving home have a smaller deposit (ie net worth) available than they otherwise would for the purchase of their next home. When they have a smaller deposit, they obtain less favourable mortgage interest rates when renegotiating their mortgage, and have less scope for extracting additional equity to finance consumption. Fluctuations in house prices significantly affect the value of houses as collateral and therefore strongly influence borrowing conditions for households.

We show, by simulation, that the financial accelerator mechanism described above amplifies and propagates the responses of the economy to various shocks. We also consider the implications of recent deregulation in the mortgage market. Our simulation shows that cheaper access to home 
equity means that, for a given house price rise, more additional borrowing will be devoted to consumption relative to housing investment. This has important implications for how house price movements should be interpreted, because it implies that the relationship between house prices and consumption has changed over time. 


\section{Introduction}

House prices in the United Kingdom, and more recently in the United States have received a great deal of attention from policy-makers and economic commentators. It is often assumed that if house prices are growing rapidly, consumption growth will be strong too. Recent minutes of the Monetary Policy Committee meetings in the United Kingdom support this view: '...the continuing strength in house prices would tend to underpin consumption...' (April 2001). Similarly, the Fed Chairman Alan Greenspan stated 'And thus far this year, consumer spending has indeed risen further, presumably assisted in part by a continued rapid growth in the market value of homes' (Monetary Policy Report to Congress, 18 July 2001). But the economic links between house prices and economic activity are complex. In this paper we focus on the role of housing as collateral for household borrowing. To justify our treatment of housing as distinct from other assets, it is useful to consider why houses are different. Most consumers live in the houses they own and value directly the services provided by their home. So the benefit of an increase in house prices is directly offset by an increase in the opportunity cost of housing services. An increase in house prices does not generally shift the budget constraint outwards. Even if one considers finitely-lived households, the capital gain to a last-time seller of a house represents a redistribution away from a first-time buyer, so house price changes can redistribute wealth, but not increase it in aggregate. This contrasts with financial assets: an increase in, say, the value of future dividends on equities due to an increase in productivity shifts the aggregate budget constraint out and can therefore lead to an increase in aggregate consumption. So it is not obvious that there is a traditional 'wealth effect' from housing in the way that we think of a wealth effect arising from a change in the value of households' financial assets.

There are many reasons why house prices and consumption may move together. If consumers are optimistic about economic prospects, they are likely to increase their consumption of housing and non-housing goods alike. If house price increases are accompanied by an increase in housing transactions, as they often are, these transactions may have a direct effect on consumption as people buy goods that are complimentary to housing, such as furniture, carpets and major appliances. House prices also affect the economy because, as is the case in the United Kingdom, they may enter directly into the retail price index via housing depreciation, which depends on the level of house prices. Most importantly, house prices may also have a direct impact on consumption via credit market effects. Houses represent collateral for homeowners, and 
borrowing on a secured basis against ample housing collateral is generally cheaper than borrowing against little collateral or borrowing on an unsecured basis (via a personal loan or credit card). So an increase in house prices makes more collateral available to homeowners, which in turn may encourage them to borrow more, in the form of mortgage equity withdrawal (MEW), to finance desired levels of consumption and housing investment. The increase in house prices may be caused by a variety of shocks, including an unanticipated reduction in real interest rates, which will lower the rate at which future housing services are discounted.

In this paper, we model credit frictions in the consumption/house purchase decision. Our motivation is based on three observations for the United Kingdom. (i) House prices and housing investment are strongly cyclical, which leads to substantial variation in households' collateral position (or loan to value ratio, or net worth) over the business cycle. (ii) The amount of secured borrowing to finance consumption is closely related to this collateral position. (iii) The spread of mortgage rates over the risk-free interest rate varies with the collateral position of each household, and unsecured borrowing rates, which are the marginal source of finance once collateral has been exhausted, are much higher than mortgage rates. These stylised facts suggest credit frictions may be important in understanding the relationship between interest rates, house prices, housing investment and consumption. There are several empirical studies that support the importance of a credit channel in housing investment and consumption decisions. Muellbauer and Murphy $(1993,1995,1997)$ have argued that when consumers are borrowing constrained, changes in housing values can change the borrowing opportunities of consumers via a collateral effect. They find significant effects of households' access to credit on consumption and on housing investment in UK aggregate and regional data. Lamont and Stein (1999) find in US regional data that households with weak balance sheets adjust their housing demand more strongly in the face of income shocks, which they interpret as consistent with a strong role for borrowing constraints. Iacoviello and Minetti (2000) find evidence for several European countries, including the United Kingdom, that households' aggregate borrowing costs vary with aggregate balance sheet strength.

We therefore propose a general equilibrium model, based on the financial accelerator model of Bernanke, Gertler and Gilchrist (1999) (BGG hereafter), that describes how this credit market channel may form part of the monetary transmission mechanism. The model focuses on the macroeconomic effects of imperfections in credit markets. Such imperfections generate premia on the external cost of raising funds, which in turn affect borrowing decisions. Within this 
framework, endogenous developments in credit markets—such as variations in net worth or collateral—work to amplify and propagate shocks to the macroeconomy. A positive shock to economic activity causes a rise in housing demand, which leads to a rise in house prices and so an increase in homeowners' net worth. This decreases the external finance premium, which leads to a further rise in housing demand and also spills over into consumption demand.

We also consider the implications for monetary policy of recent structural changes in the United Kingdom's retail financial markets: following deregulation in the mortgage market, it became easier and cheaper for consumers to borrow against housing collateral to finance consumption. We show that cheaper access to home equity means that, for a given house price increase, more additional borrowing will be devoted to consumption relative to housing investment. The response of consumption to an unanticipated change in interest rates will therefore be larger, and the response of house prices and housing investment will be smaller. This has important implications for the information content of house prices, because it implies that, even for similar economic shocks, the relationship between house prices and consumption is changing over time.

The paper is organised as follows. Section 2 present some stylised facts and institutional features on the UK housing market. Section 3 presents some VAR evidence on the effects of monetary policy on housing variables. Sections 4 and 5 describe the model in detail. Section 6 presents simulated results for several scenarios of interest. Section 7 concludes.

\section{A brief description of the UK housing market}

Charts 1.1 to 1.3 show the changes in the key housing variables ${ }^{(1)}$ (house prices and housing investment) and GDP over the period since 1970. House prices move strongly with GDP, though with a slight lag. Housing investment, on the other hand, clearly leads the output cycle. Housing investment and house prices also move closely together, with housing investment leading house prices.

Chart 1.4 shows the changes in house prices and consumption. Breaking down consumption into durables and non-durables, the strongest relationship seems to be that between house prices and consumption of durable goods (see Charts 1.5 and 1.6). This is consistent with a household credit

(1) All variables have been detrended by taking logs and then regressing on a constant, a linear trend and a quadratic trend. 
channel, as purchases of durable goods are more likely to be financed by borrowing, and so will be more sensitive to changes in interest rates if there are frictions in the market for credit. If changes in the extent of credit conditions are in turn correlated with fluctuations in house prices-for example if house prices proxy the availability of housing collateral—-then this could generate a strong correlation between house prices and durable goods consumption. ${ }^{(2)}$

Table A shows the correlation of house prices with key macroeconomic variables at several leads and lags. This confirms our assertion that house prices slightly lag the cycle. Based on the peak correlation coefficient, house prices lag movements in GDP and non-durables consumption by 1-2 quarters, and house prices lag housing investment and durables consumption by 4 quarters.

Table A: Correlation of house prices with aggregate variables

\begin{tabular}{llllllll}
\hline \hline & $H P_{t-3}$ & $H P_{t-2}$ & $H P_{t-1}$ & $H P_{t}$ & $H P_{t+1}$ & $H P_{t+2}$ & $H P_{t+3}$ \\
\hline$G D P_{t}$ & 0.47 & 0.57 & 0.65 & 0.71 & 0.74 & 0.74 & 0.71 \\
$C_{t}$ & 0.67 & 0.77 & 0.84 & 0.90 & 0.92 & 0.92 & 0.88 \\
$H I_{t}$ & 0.15 & 0.25 & 0.37 & 0.50 & 0.60 & 0.68 & 0.73 \\
$D C_{t}$ & 0.29 & 0.43 & 0.56 & 0.68 & 0.76 & 0.81 & 0.83 \\
$N D C_{t}$ & 0.72 & 0.80 & 0.85 & 0.89 & 0.90 & 0.88 & 0.83 \\
\hline \hline
\end{tabular}

Table B shows the standard deviation of these variables, as well as their relative standard deviation to that of GDP. House prices, housing investment and durables consumption are respectively 5.3, 4.4 and 3.6 times as volatile as GDP, whereas non-durables consumption has a similar standard deviation to GDP.

Table B: Absolute and relative standard deviations of detrended variables

\begin{tabular}{lll}
\hline \hline & std.dev. & std.dev relative to GDP \\
\hline$H P$ & 0.140 & 5.3 \\
$G D P$ & 0.027 & 1 \\
$C$ & 0.035 & 1.3 \\
$H I$ & 0.118 & 4.4 \\
$D C$ & 0.097 & 3.6 \\
$N D C$ & 0.032 & 1.2 \\
\hline \hline
\end{tabular}

Because part of the motivation for this paper was the changing nature of the credit mechanism over time due to financial deregulation, we outline briefly the major stages of this deregulation in the United Kingdom during the 1980s. First were the removal of exchange controls in 1979 and the direct control of bank lending ('the Corset') in 1980. A number of measures (such as the

(2) Note that a strong correlation between house prices and durable goods consumption could also arise because both goods are 'lumpy', ie they provide services that last several years. So when consumers learn about an increase in their lifetime income, they are likely to increase their immediate demand for durable goods, including housing, more than for non-durable goods. Nevertheless, it is difficult to achieve the observed amplitude of house prices in a model without credit frictions. 


\section{Chart 1: The UK housing market}
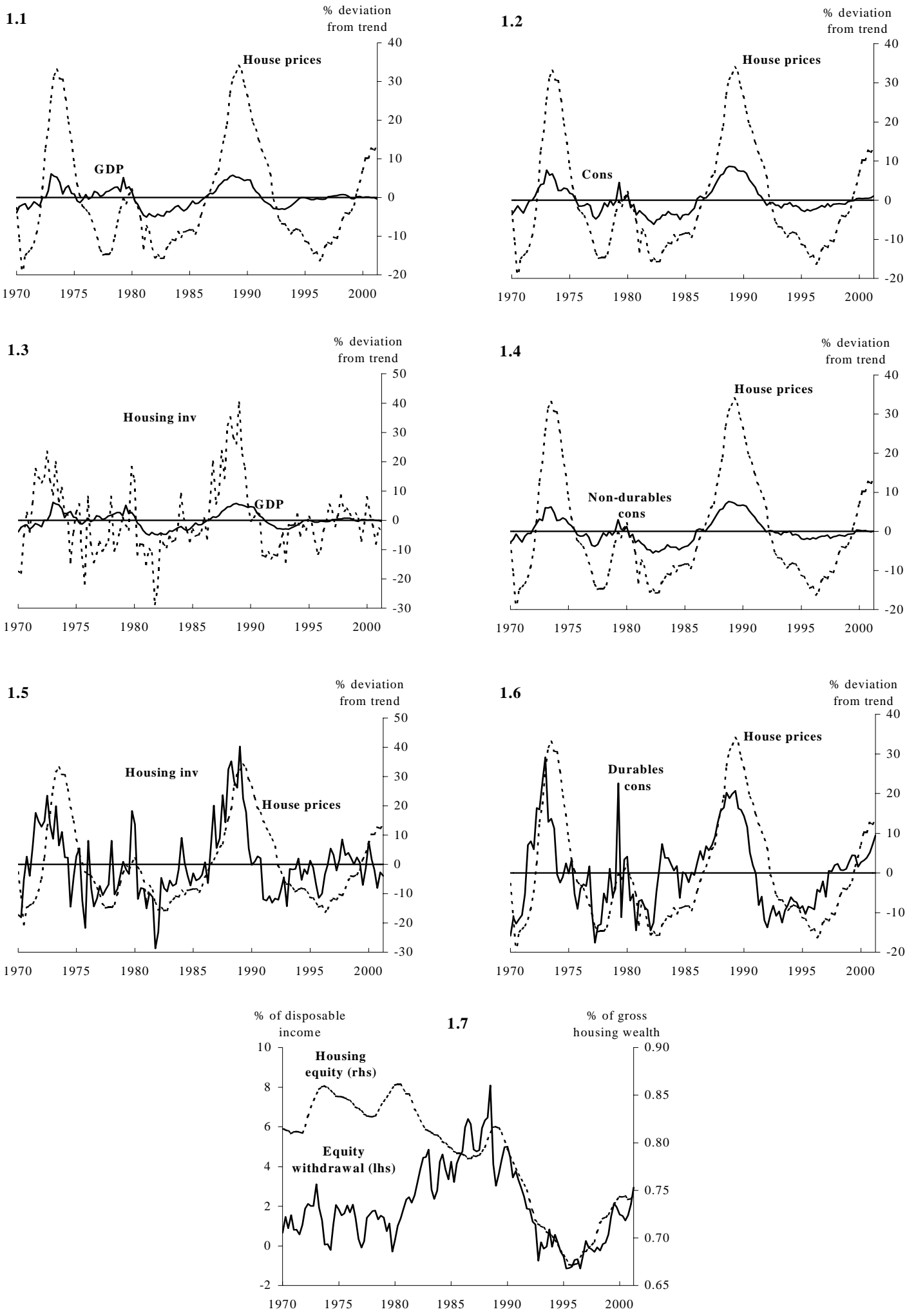
Building Societies Act (1986)) have lifted the restrictions on how building societies operate to give them the same status as banks. Other non-bank entrants-particularly department stores, retailers and insurance companies - have also increasingly been able to offer selected retail financial services, such as credit cards, unsecured loans and mortgage products. For mortgages in particular, the restrictions in place in the 1970s and early 1980s had the effect of making withdrawal of equity difficult, if not impossible: homeowners generally needed to move house to increase the value of their loan, and even then binding loan-to-value restrictions may have limited the extent of the increase (Wilcox (1985)). ${ }^{(3)}$

As competition increased and restrictions were lifted, households have been able to extract equity more easily when house prices rise. Chart 1.7 shows the relationship between aggregate net housing equity and secured borrowing for consumption, or mortgage equity withdrawal (MEW). ${ }^{(4)}$ Prior to the mid-1980s, there was little relationship between housing equity and mortgage equity withdrawal. When the market was dominated by building societies and subject to rationing, withdrawing additional equity generally required homeowners to move house, which carried high transaction costs. MEW has become more closely linked to movements in net housing equity as new mortgage products allowing refinancing or additional borrowing at ever-lower transaction costs have become available. The increased use of flexible mortgages (which resemble a secured line of credit) suggests that this trend is likely to continue. Such products are driving the transaction cost of withdrawing additional equity towards zero.

\section{The effect of monetary policy on house prices: some VAR results}

As the relationship between consumption and house prices suggests that a household credit channel may be part of the monetary transmission mechanism, we investigate how house prices are affected by monetary policy. We estimate a small vector autoregression (VAR) model to help evaluate and calibrate our theoretical model. Of course, since we will be arguing throughout this paper that the 1980s are likely to have seen an important change in the transmission mechanism,

(3) There is another financial innovation, which we do not consider in this paper, that is likely to have had an effect on the behaviour of house prices. In the 1970s and early 1980s building societies collectively agreed the mortgage and deposit rates they offered, and were reluctant to change rates frequently. When market interest rates were rising, building societies would end up with below-market interest rates. This reduced the supply of deposits, which was their main source of funding (see Pratt (1980) and Wilcox (1985) for an exposition of these mechanisms). Because building societies were also the main provider of mortgages, interest rate rises had a direct effect on the supply of mortgage loans, which is likely to have amplified any effect of interest rates on house prices.

(4) Broadly speaking, the data series constructed by the Bank of England for secured borrowing for consumption (or MEW) is constructed as total mortgage borrowing less investment in housing. 
these VAR results must not be taken too literally. We present them for illustrative purposes. The VAR includes quarterly output, inflation, oil prices and the short-term interest rate set by the Bank of England. The oil price is included in this system to reduce the price puzzle. ${ }^{(5)}$ To this we add variables of interest. The sample period, after adjusting for lags, is 1975:2 to 1999:4 and 6 lags were used. ${ }^{(6)}$ To identify the monetary policy shock, we order the policy rate last in a recursive identification structure. The implied identifying restriction is that the monetary authorities observe contemporaneous variables when setting interest rates, but all variables respond with a lag to monetary policy shocks. The impulse responses accord with our priors about the effects of monetary policy. The impulse response functions to a monetary tightening (ie a positive interest rate shock) are attached as Chart 2. Real money balances fall in response to an unexpected monetary tightening. Output falls, and the price level falls after some lag. House prices, housing investment and consumption respond negatively to an unexpected monetary tightening. Housing investment responds more quickly than house prices, and falls by more. The peak response in housing investment occurs after two quarters. The peak response to a 50 basis point shock is estimated to be about 180 basis points. The peak response in house prices occurs later, after five quarters, but is smaller at 80 basis points. Durable goods consumption responds more strongly to a monetary tightening than non-durable goods consumption. The estimated effect of a 50 basis point monetary policy shock on durables consumption is about 80 basis points, whereas the response of non-durables consumption is only 10 basis points. ${ }^{(7)}$

\section{Modelling the household credit channel}

To analyse more formally the implications of financial innovations for the transmission mechanism of monetary policy, a model is needed. Here we sketch the intuitive outline of the model used for the analysis in the subsequent sections. Our hypothesis is that house prices play a role because housing is used as collateral to reduce the agency costs associated with borrowing to finance housing investment and consumption. Our approach is to apply the BGG model of financial

(5) The price puzzle is the finding that inflation rises following a contractionary monetary policy shock. One interpretation of this finding is that supply variables are not adequately accounted for in the model, and systematic responses of monetary policy to supply shocks (tightening when inflation is rising) are then misinterpreted as monetary policy shocks. Including a proxy for supply shocks in the system (such as oil prices) will help identification of 'true' monetary. For a discussion of the price puzzle, see, for example, Sims (1992).

(6) We started with 8 lags and tested down using likelihood ratio tests. The null hypothesis of 5 lags against an alternative hypothesis of 6 lags was rejected at the $1 \%$ confidence interval.

(7) The standard-error bands on these impulse response functions are large, because by incorporating all variables at once we have sacrificed degrees of freedom. Introducing variables one by one, as in Christiano, Eichenbaum and Evans (1996) reduces the standard-error bands but leaves patterns of the responses broadly unchanged. We only report the more conservative results, based on the full system. 


\section{Chart 2: VAR impulse responses to a monetary policy shock}
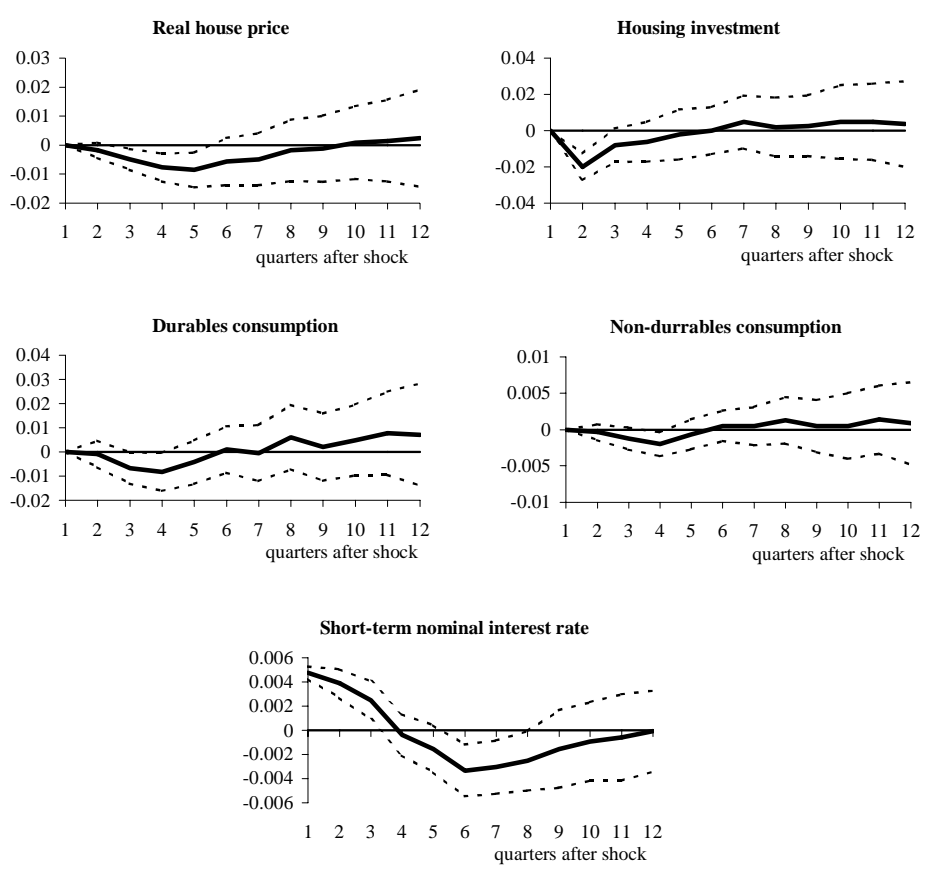

acceleration in the corporate sector to the household sector. The BGG framework links the cost of firms' external finance to the quality of their balance sheet. Because there are parallels between housing investment and business investment, and between house prices and the value of business capital goods, the BGG model provides a useful platform on which to build a model where house prices, housing investment and consumption interact in a general equilibrium framework.

So how should we think of credit frictions in the household sector? Households are exposed to the idiosyncratic risk of fluctuations in their house prices. On its own, this is not sufficient to generate a credit channel. But personal bankruptcy is associated with significant monitoring costs faced by lenders. Lenders therefore charge a premium over the risk-free interest rate to borrowers. Higher net worth—or lower leverage_-reduces the probability of default, and therefore reduces the external finance premium.

In practice, fluctuations in the external finance premium may best be thought of in the following way. When house prices fall, households that are moving home have a smaller deposit (ie net worth) available than they otherwise would for the purchase of their next home. When they have a smaller deposit, they obtain less favourable mortgage interest rates when renegotiating their 
mortgage, and have less scope for extracting additional equity to finance consumption. Once they have exhausted their collateralised borrowing possibilities, any further borrowing can only be achieved with unsecured credit, which carries much higher interest rates than secured borrowing. ${ }^{(8)}$ Since house prices significantly affect the collateral value of houses, fluctuation in housing prices plays a large role in the determination of borrowing conditions of households.

The main modelling issue is how to generate both consumer borrowing and lending within a general equilibrium framework, ${ }^{(9)}$ without losing tractability and comparability with benchmark macro models. To avoid the complexity inherent in modelling the dynamic optimisation problem of heterogeneous consumers under liquidity constraints, we represent consumer behaviour in a rather stylised way. That is, we think of each household as being a composite of two behavioural types: homeowners and consumers. This separation makes the analysis significantly simpler, but without losing the essence of the financial accelerator mechanism.

On the one hand, 'homeowners' borrow funds to purchase houses from housing producers. Homeowners purchase houses and rent them to consumers. This flow of rental payments within households is captured in the UK national accounts as imputed rents. Homeowners finance the purchase of houses partly with their net worth and partly by borrowing from financial intermediaries. When borrowing from financial intermediaries, homeowners face an external finance premium caused by information asymmetries, just as firms are assumed to do in BGG.

On the other hand, consumers consume goods and housing services. They also supply labour in a competitive labour market. Consumers are assumed to rent housing services from the homeowners. Consumers and homeowners are further linked by a 'transfer' rule that homeowners pay to consumers. ${ }^{(10)}$ This assumption captures the fact that households use their housing equity to finance consumption as well as housing investment. When house prices increase-and therefore housing equity rises - the household faces the following decision problem. If it increases the transfer and hence consumption today, current household utility would go up. But, if transfer payments were kept constant, net worth would increase, reducing the future external finance

(8) For example, the March 2002 quoted average interest rates on variable rate mortgages were 1.65 percentage points above the policy rate. Unsecured personal loans and credit cards were charged interest rates of respectively 7.90 and 12.70 percentage points above the policy rate. (MoneyFacts, March 2002.)

(9) Many models of household saving behaviour assume the overlapping generations framework to ensure both borrowing and lending occurs in equilibrium. See for example, Gourinchas (2000), and Gertler (1999).

(10) Alternatively, one can interpret homeowners as firms who are owned by households and rent houses to the household sector. Then the transfer is equivalent to a dividend paid back to the households. 


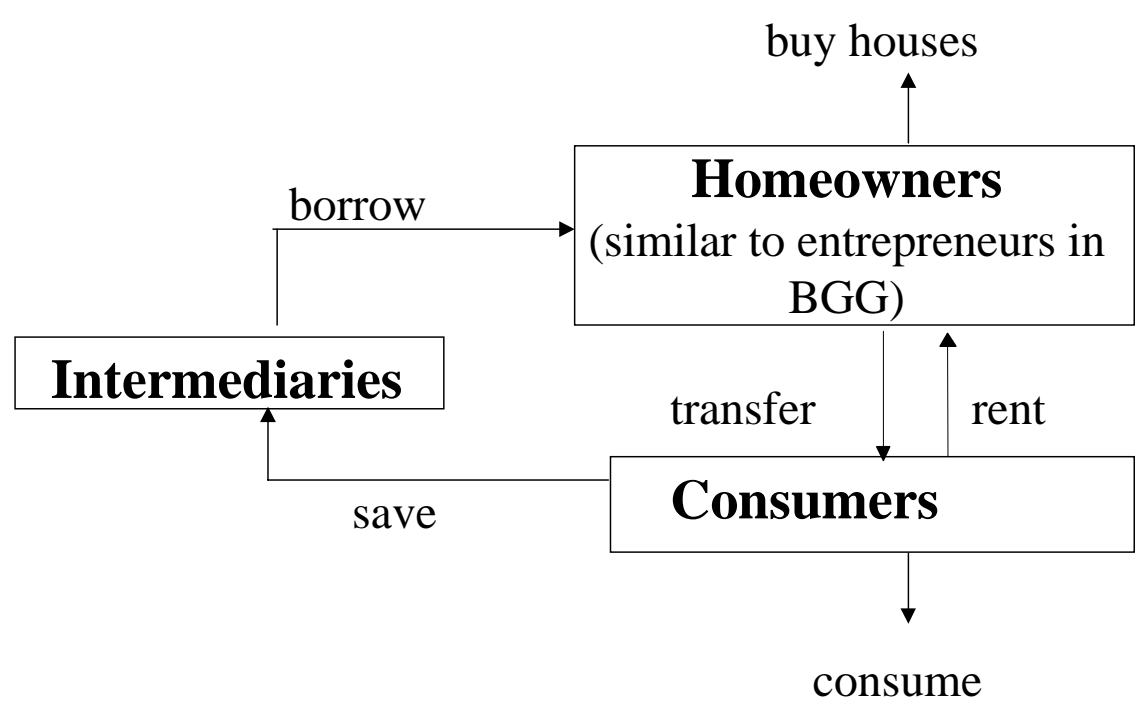

premium. Thus the household faces a choice between current consumption and a cheaper future finance premium. The optimal allocation-and hence transfer payment-would depend on such factors as the elasticity of intertemporal substitution, the sensitivity of the external finance premium with respect to household net worth, and future income uncertainty. In general, there exists a target level of net worth relative to debt (ie leverage), and transfers depend on the deviation of leverage from target. Here we assume a transfer rule that captures the households' decision described above. Transfers are assumed to be increasing in the net worth of the households relative to their debt.

Fluctuations in transfers described in our model can be thought of as borrowing against home equity for consumption (MEW). If we interpret transfers as MEW, then the sensitivity of transfers with respect to home equity will also depend on the transaction costs involved in MEW. Keeping other things constant, if it is less costly to withdraw mortgage equity, MEW becomes more sensitive to households' financial positions and hence to house prices.

In this way, we are able to capture in a parsimonious form the ideas that some elements of the household sector saves while others borrow, and that this process is intermediated through financial markets with credit frictions. To emphasise the idea that consumers and homeowners form part of the same composite household, we illustrate the flow of funds within our model in Chart 3. 
We also assume two types of consumers. Some fraction of consumers has accumulated enough wealth, so that their consumption is well approximated by the permanent income hypothesis $(\mathrm{PIH})$. Their consumption satisfies the standard Euler equation. On the other hand, the consumption of a certain fraction of the population does not. If these consumers are impatient (in the sense of Carroll (1997)), or if they are subject to borrowing constraints, their behaviour is similar to rule-of-thumb (ROT) consumers (Campbell and Mankiw (1989)) who spend their current income in each period. Their consumption in each period is equal to their labour income and transfers from the homeowners. To be clear, the ROT consumers are not cut off from all borrowing possibilities, but are assumed to borrow only when the increase in the value of their house gives them access to additional borrowing opportunities. These opportunities in our model are captured by the transfer payment, which should be interpreted as 'borrowing against the value of your house to finance consumption'.

The rest of our model is standard and broadly follows BGG. We introduce nominal price stickiness in the consumption goods sector so that monetary policy has real effects. Specifically, we assume the Calvo (1983) staggered price setting (see, for example, Woodford (1996), Rotemberg and Woodford (1999), McCallum and Nelson (1999)). House prices are determined by a q-theory of investment with a convex adjustment cost. Monetary policy is assumed to follow a standard Taylor-type feedback rule.

There is large literature, both theoretical and empirical, on consumer behaviour under liquidity constraints. ${ }^{(11)}$ This line of research develops rigorous models of optimal households' behaviour under liquidity constraints and income uncertainty. Our model should not be interpreted as an alternative approach to the analysis of consumption and saving under liquidity constraints. Rather, a major challenge for this branch of the literature has been that the solution of household optimisation problems under liquidity constraints and uncertainty is very complex. As a result, the construction of a tractable general equilibrium model is extremely difficult. Our approach offers the opportunity to capture many of the implications of this literature for the transmission mechanism of monetary policy in a simple way. We now turn to the derivation of the model.

(11) See, for example, Deaton (1991,1992), Carroll (1997), Gourinchas (2000). Although much of the literature focuses on non-durable consumption, Carroll and Dunn (1997) consider the effects of household balance sheet on consumption of both non-durable goods and housing. 


\section{The model}

\subsection{Preferences}

Our treatment of preferences is standard. Consumers consume differentiated consumption goods and housing services. The period-utility of household $i$ is given by

$$
\log C_{t}^{i}+\xi \log \left(1-L_{t}^{i}\right), \quad \xi>0
$$

where $L^{i}$ denotes labour, and $C_{t}^{i}$ denotes a CES consumption aggregator of form

$$
C_{t}^{i}=\left[\gamma^{\frac{1}{\eta}}\left(c_{t}^{i}\right)^{\frac{\eta-1}{\eta}}+(1-\gamma)^{\frac{1}{\eta}}\left(h_{t}^{i}\right)^{\frac{\eta-1}{\eta}}\right]^{\frac{\eta}{\eta-1}}
$$

Here $c_{t}^{i}$ is a Dixit-Stiglitz aggregator of differentiated consumption goods, and $h_{t}^{i}$ denotes housing services. The differentiated goods is indexed by $z \in(0,1)$, and the Dixit-Stiglitz aggregator for consumption goods is defined as

$$
c_{t}^{i}=\left[\int_{0}^{1} c_{t}^{i}(z)^{\frac{\varepsilon-1}{\varepsilon}} d z\right]^{\frac{\varepsilon}{\varepsilon-1}}
$$

The corresponding price index for consumption goods is given by

$$
P_{c, t}=\left[\int_{0}^{1} 1 p_{t}(z)^{1-\varepsilon} d z\right]^{\frac{1}{1-\varepsilon}}
$$

Given a level of composite consumption $C_{t}^{i}$, intra-period utility maximisation implies the following demand functions for each good

$$
\begin{gathered}
c_{t}^{i}=\gamma\left(\frac{P_{c, t}}{P_{t}}\right)^{-\eta} C_{t}^{i} \\
h_{t}^{i}=(1-\gamma)\left(\frac{P_{h, t}}{P_{t}}\right)^{-\eta} C_{t}^{i}
\end{gathered}
$$

where $P_{c, t}$ and $P_{h, t}$ denote prices of consumption goods and rental price of housing, respectively. The composite price index, $P_{t}$, is defined as

$$
P_{t}=\left[\gamma P_{c, t}^{1-\eta}+(1-\gamma) P_{h, t}^{1-\eta}\right]^{\frac{1}{1-\eta}}
$$

Demand for each of the consumption goods is given by

$$
c_{t}^{i}(z)=\left(\frac{p_{t}(z)}{P_{c, t}}\right)^{-\varepsilon} c_{t}^{i}
$$

We defer intertemporal decision problems to Section 5.3 and turn to the description of house purchase decisions. 


\subsection{House purchase decisions}

The house purchase decisions of the household sector are made by homeowners. Their problem is modelled in an identical way to the investment decisions of firms in the BGG model. Homeowners purchase houses from housing producers at a price $Q_{t}$, and rent houses to their consumers at a rental price $P_{h, t+1}$. Homeowners face an external finance premium, caused by financial market imperfections. Homeowners are risk neutral. As pointed out by BGG and Bernanke and Gertler (1989), this assumption makes both the underlying contract structure and aggregation much simpler. We also assume that homeowners pay transfers to consumers, as discussed later.

At the end of period $t$, a homeowner purchases a house at nominal price $Q_{t}$ and rents it to the consumers within their household in the subsequent period $t+1$ at a rental price $P_{h, t+1}$. It finances the purchase of houses partly with its own net worth available at the end of period $t, N_{t+1}$, and partly by borrowing, $b_{t+1}$. In real terms, the finance of houses is given by

$$
q_{t} h_{t+1}=N_{t+1}+b_{t+1}
$$

where $q_{t}=\frac{Q_{t}}{P_{t}}$ is the real price of houses.

Homeowners' demand for houses depends on the expected return on housing and expected marginal financial cost. One unit of housing purchased at time $t$ and rent at time $t+1$ yields the expected gross return, $R_{h, t+1}$, given by

$$
E_{t}\left[R_{h, t+1}\right]=E_{t}\left[\frac{X_{h, t+1}+(1-\delta) q_{t+1}}{q_{t}}\right]
$$

where $0<\delta<1$ is the depreciation rate of houses and $X_{h, t+1}$ is the rental price relative to the composite price index.

The marginal borrowing cost for a homeowner depends on its financial condition. Following BGG, we assume the existence of an agency problem that makes uncollateralised external finance more expensive than internal finance. We do not explicitly present the underlying agency problem here: rather we observe that the external finance premium $f(\cdot)$ can be expressed as a decreasing function of the leverage ratio, $N_{t+1} / q_{t} h_{t+1}$. We have in mind a costly state verification problem similar to that described in BGG: banks cannot perfectly observe the borrower's ability to repay and banks face an auditing cost to verify repayment ability. The optimal contract will therefore be a debt contract, and when the borrower announced he is unable to repay, the bank takes possession of all the borrower's assets. In the household context, these auditing costs can be interpreted as the 
costs of legal proceedings to the value the borrower's assets and the administration costs of selling the house to realise its collateral value. When there is aggregate uncertainty, the interest payable on the debt contract will be linked to fluctuations in the default probablity, which is in turn determined by the leverage of the borrower. The marginal cost of borrowing is given by $f\left(N_{t+1} / q_{t} h_{t+1}\right) R_{t+1}, f^{\prime}<0$, where $R_{t}$ is the risk-free real interest rate. The optimal condition for the homeowner's demand for housing should satisfy

$$
E_{t}\left[R_{h, t+1}\right]=f\left(N_{t+1} / q_{t} h_{t+1}\right) R_{t+1}
$$

As is shown in BGG, risk neutrality implies that all homeowners choose the same leverage ratio, so equation (3) holds for the aggregate level.

The other key aspect is the equation that describes the evolution of net worth of the homeowner. Let $V_{t}$ denote the value of homeowners at the beginning of period $t$, net of borrowing costs. It is given by

$$
V_{t}=R_{h, t} q_{t-1} h_{t}-f\left(N_{t} / q_{t-1} h_{t}\right) R_{t} b_{t-1}
$$

where $R_{h, t}$ is the ex post return from housing.

As indicated above, we also assume that homeowners pay transfers, $D_{t}$, to consumers in the household. We will discuss $D_{t}$ in detail later. The homeowner's net worth after he or she pays the transfer is given by

$$
N_{t+1}=V_{t}-D_{t}
$$

Note that the price of houses, $q_{t}$, may have significant effects on the net worth, as the first term in equation (4) can be written as

$$
R_{h, t} q_{t-1} h_{t}=\left(X_{h, t}+(1-\delta) q_{t}\right) h_{t}
$$

Thus the price of houses may have strong effects on the net worth and borrowing conditions of households.

Transfers in our model represent the distribution of housing equity (including imputed rent income) between homeowners and consumers. ${ }^{(12)}$ Here we model transfer policy in a simple way, but keeping consistency with underlying economic theory as much as possible. In the economy's steady state—where the leverage ratio is constant—-transfers should equal homeowners' rent income minus interest payments and a depreciation allowance. ${ }^{(13)}$ In other words, the transfer in

(12) On the income side of national accounting, imputed rent is counted as household's gross operating surplus.

(13) This condition does hold in the steady state of our model. 
steady state is equal to the net return on homeowners' net worth. Consumers can spend this dividend income for consumption.

When house prices increase- and therefore the value of the homeowners, $V_{t}$ - the household faces the following decision problem. If it increased the transfer and hence consumption today, current household utility would go up. But, if transfer payments were kept constant, net worth would increase, reducing the future external finance premium. Thus the household faces a trade-off between current consumption and a cheaper future premium. The optimal allocation-and hence transfer payment-would depend on factors such as the elasticity of intertemporal substitution, and the slope of function $s(\cdot)$, and future income uncertainty. ${ }^{(14)}$

We assume a dividend rule that captures the households' decision described above. Transfers are increasing in the net worth of households relative to their debt. That is, the transfer rule is

$$
D_{t}=\chi\left(N_{t+1} / q_{t} h_{t+1}\right)
$$

where $\chi^{\prime}>0$ and $\chi(\phi)=D$. Here $\phi$ is the leverage ratio in the steady state, and $D$ is the level of dividend consistent with $\phi .{ }^{(15)}$

Of course, in a fully micro-founded model, transfers would also depend on other factors, such as uncertainty about future labour income. However, much of our analysis below, in particular the analysis of the effect of house prices on consumption, would go through if we considered a more micro-founded transfer rule.

\section{3 (Intertemporal) consumption decisions}

Now we turn to describe intertemporal consumption decisions. As stated we consider two types of household. A certain fraction of households have accumulated enough wealth so that their consumption decisions are well approximated by the permanent income hypothesis. The other households do not have enough wealth to smooth consumption. If they are facing borrowing constraints or if they are impatient, their marginal propensity to consume out of current income is

(14) The literature on consumption under liquidity constraints studies extensively the implications of labour income uncertainty on optimal consumption-saving decisions. The optimal allocation between transfers (consumption) and retained net worth in our model may have a similar structure, if the model were fully micro-founded.

(15) When we calibrate the model, $\phi$ is set equal to the average leverage ratio of the UK household sector. This is given by 0.7 . 
higher than PIH consumers. We approximate these consumers as rule-of-thumb consumers. ${ }^{(16)}$

\subsubsection{PIH consumers}

The assumptions concerning PIH consumers are fairly conventional. The representative PIH consumer can borrow or lend at the (real) riskless rate of return, $R_{t}$, and his objective is given by

$$
\max E_{t} \sum_{k=0}^{\infty} \beta^{k}\left[\log C_{t+k}^{p}+\xi \log \left(1-L_{t+k}^{p}\right)\right]
$$

Solving the PIH household's problem yields standard first-order conditions for (composite) consumption and labour supply

$$
\begin{gathered}
\frac{1}{C_{t}^{p}}=\beta E_{t}\left(\frac{1}{C_{t+1}^{p}}\right) R_{t+1} \\
w_{t}\left(1-L_{t}^{p}\right)=\xi C_{t}^{p}
\end{gathered}
$$

where $w_{t}$ is real wage (in terms of composite goods).

\subsubsection{Rule-of-thumb consumers}

Following Campbell and Mankiw (1989) and others, we assume the ROT consumers consume their current income: that is, the sum of wage income and the transfer paid out by homeowners. In this framework, the ROT consumers have access to mortgage equity withdrawal (MEW), but not to non-secured loans, and the amount they can borrow against the value of their house is represented by the transfer paid out by homeowners. The (composite) consumption of the ROT consumers is given by

$$
C_{t}^{r}=w_{t} L_{t}^{r}+D_{t}
$$

where $D_{t}$ denotes the transfer they receive from homeowners. ${ }^{(17)}$ The labour supply of the ROT consumers is given by

$$
w_{t}\left(1-L_{t}^{p}\right)=\xi C_{t}^{p}
$$

Let $0<n<1$ be a fraction of PIH consumers in the economy. Aggregate consumption is then

$$
C_{t}=n C_{t}^{p}+(1-n) C_{t}^{r}
$$

(16) An alternative way of getting similar results is to assume patient and impatient consumers, as in Iacoviello (2002). In his model, the impatient consumers behave like our ROT consumers.

(17) Bernanke and Gertler (2000) have a similar assumption about entrepreneurs' consumption to generate wealth effects from stock prices. 
and demands for each of the consumption goods and housing services are

$$
c_{t}=\gamma\left(\frac{P_{c, t}}{P_{t}}\right)^{-\eta} C_{t} \equiv \gamma X_{c, t}^{-\eta} C_{t}
$$

and

$$
h_{t}=(1-\gamma)\left(\frac{P_{h, t}}{P_{t}}\right)^{-\eta} C_{t} \equiv(1-\gamma) X_{h, t}^{-\eta} C_{t}
$$

Aggregate labour supply is defined as

$$
L_{t}=n L_{t}^{p}+(1-n) L_{t}^{r}
$$

Finally, from (8) and (10) wage is determined as

$$
w_{t}\left(1-L_{t}\right)=\xi C_{t}
$$

\subsection{House producers}

House prices are determined by a q-theory of investment. We assume that house producers purchase consumption goods and use them to produce new houses. Investment of $I_{t}$ units of composite consumption goods yields $h_{t+1}=\Phi\left(I_{t} / h_{t}\right) h_{t}$ units of new housing stock, where $\Phi(\cdot)$ is assumed to be concave. The assumption of concavity implies convex adjustment costs of housing investment. In equilibrium, the price of housing is given by

$$
\frac{q_{t}}{X_{c, t}}=\Phi^{\prime}\left(\frac{I_{t}}{h_{t}}\right)
$$

where $X_{c, t}$ is the price of consumption goods relative to the composite price index. As discussed above, changes in house prices will affect the balance sheets of the household sector, and hence their cost of borrowing.

\subsection{Producers of consumption goods}

For simplicity, we assume capital is fixed and labour is the only variable input. We assume a Cobb-Douglas production function of the form

$$
y_{t}(z)=A_{t} \bar{K}(z)^{\alpha} L_{t}(z)^{1-\alpha}
$$

Following the large literature on monetary business cycles, we assume that prices of consumption goods are sticky. Specifically, we assume the Calvo (1983) staggered price setting (see, for example, Woodford (1996), Rotemberg and Woodford (1999)). In each period, only a fraction $\theta$ of sellers are allowed to change their prices. The seller indexed $z$ who gets a chance to change his 
price, chooses his price in order to maximise

$$
E_{t} \sum_{k=0}^{\infty} \theta^{k} \frac{\Lambda_{t, t+k}}{P_{t+k}}\left[p_{t}(z) y_{t+k}(z)-W_{t+k} L_{t+k}(z)\right]
$$

subject to its demand condition

$$
y_{t+k}(z)=\left(\frac{p_{t}(z)}{P_{c, t+k}}\right)^{-\varepsilon} Y_{t+k}
$$

where $\Lambda_{t, t+k}$ is the shareholder's intertemporal marginal rate of substitution. The term $Y_{t}$ denotes aggregate demand for consumption goods. This consists of consumption demand, investment demand, and government expenditure. That is,

$$
Y_{t}=c_{t}+I_{t}+G_{t}
$$

The first-order condition for optimal pricing is given by

$$
E_{t} \sum_{k=0}^{\infty} \theta^{k} \Lambda_{t, t+k}\left[\frac{P_{c, t+k}}{P_{t+k}}\left(\frac{p_{t}(z)}{P_{c, t+k}}\right)^{-\varepsilon} Y_{t+k}\left\{\frac{p_{t}(z)}{P_{c, t+k}}-\frac{\varepsilon}{\varepsilon-1} m c_{t+k}\right\}\right]=0
$$

where $m c_{t+k}$ is real marginal cost at time $t+k$ in terms of consumption goods, given by

$$
\frac{W_{t+k}}{P_{c, t+k}}\left(\frac{y_{t+k}(z)}{A_{t+k}}\right)^{\frac{1}{1-\alpha}}
$$

In the next section, we use the model to illustrate the implications for monetary policy of recent financial innovations. The full log-linearised model is described in the appendix.

\section{Model simulations}

\subsection{With and without financial accelerator}

So how does the financial accelerator work in our world? A positive shock to the economy causes a rise in housing demand, which leads to a rise in house prices and a rise in homeowners' net worth. This causes decrease in the external finance premium, which leads to a further rise in housing demand and a rise in the transfer paid back to consumers. This rise in the transfer generates a further increase in consumption. As in BGG, credit market frictions amplify and propagate shocks to the economy.

In this section, we present some impulse responses of the model to an expansionary monetary policy shock. ${ }^{(18)}$ For the baseline financial accelerator model, the steady state annual external finance premium is assumed to be 200 basis points, and the ratio of net worth to capital is 0.7 ,

(18) Here we set a monetary policy shock as a 50 basis points (annualised) fall in nominal interest rates. This corresponds approximately to a one standard deviation monetary policy shock from the estimated VAR. 
which is the average historical leverage ratio of UK households. The elasticity of the transfer with respect to housing equity is set at 3 . This is the estimated average elasticity of mortgage equity withdrawal with respect to the net worth ratio. In Section 6.2, we experiment with changes in this parameter. Lastly, the share of rule-of-thumb consumers is set at 0.5. For the United Kingdom, there is no consensus on this share in the literature, but a reasonable range appears to be 0-0.6 (Bayoumi (1993), Jappelli and Pagano (1989), Campbell and Mankiw (1989)). We use 0.5 as our baseline scenario. The parameterisation of the full model is discussed in the appendix. Chart 3 shows the impulse responses with and without the financial accelerator. In response to a 50 basis points monetary policy shock, a baseline model with the financial accelerator turned off produces peak responses in consumption, house prices and housing investment of 56 basis points, 48 basis points and 111 basis points respectively. Compared to the VAR results in Section 3, both the house price and housing investment response are too low. When the financial accelerator is switched on, those same responses increase to 66 basis points, 99 basis points and 214 basis points respectively, much more in line with the VAR evidence.

\subsection{Increased access to housing equity}

In Section 2, we discussed that the transaction cost of extracting equity from housing has fallen, and that product development is likely to reduce them further in coming years: mortgage equity withdrawal and net housing equity have become more closely linked (Chart 1.7). In this section we examine the implications of this structural change for monetary policy.

In our model, households face a trade-off when house prices rise: they can either withdraw the additional equity for consumption or they can use their stronger balance sheet to lower the rate at which they can borrow. This trade-off is captured by the adjustment parameter on the transfer stream between the house-owning and consuming part of the household. When transaction costs fall, it increases the elasticity of the transfer with respect to housing equity.

Chart 4 shows the responses of key variables to an unexpected monetary policy loosening when the elasticity of transfer with respect to housing equity is changed from 3 to $30 .{ }^{(19)}$ The net effect of reducing transaction costs on housing investment and house prices is to dampen the response to the policy loosening (from 214 basis points to 110 basis points for housing investment, and from

(19) The estimated elasticity of MEW with respect to net housing equity over the recent period 1990-2000 is 30. 
Chart 4: Responses to a monetary policy shock: with and without credit frictions
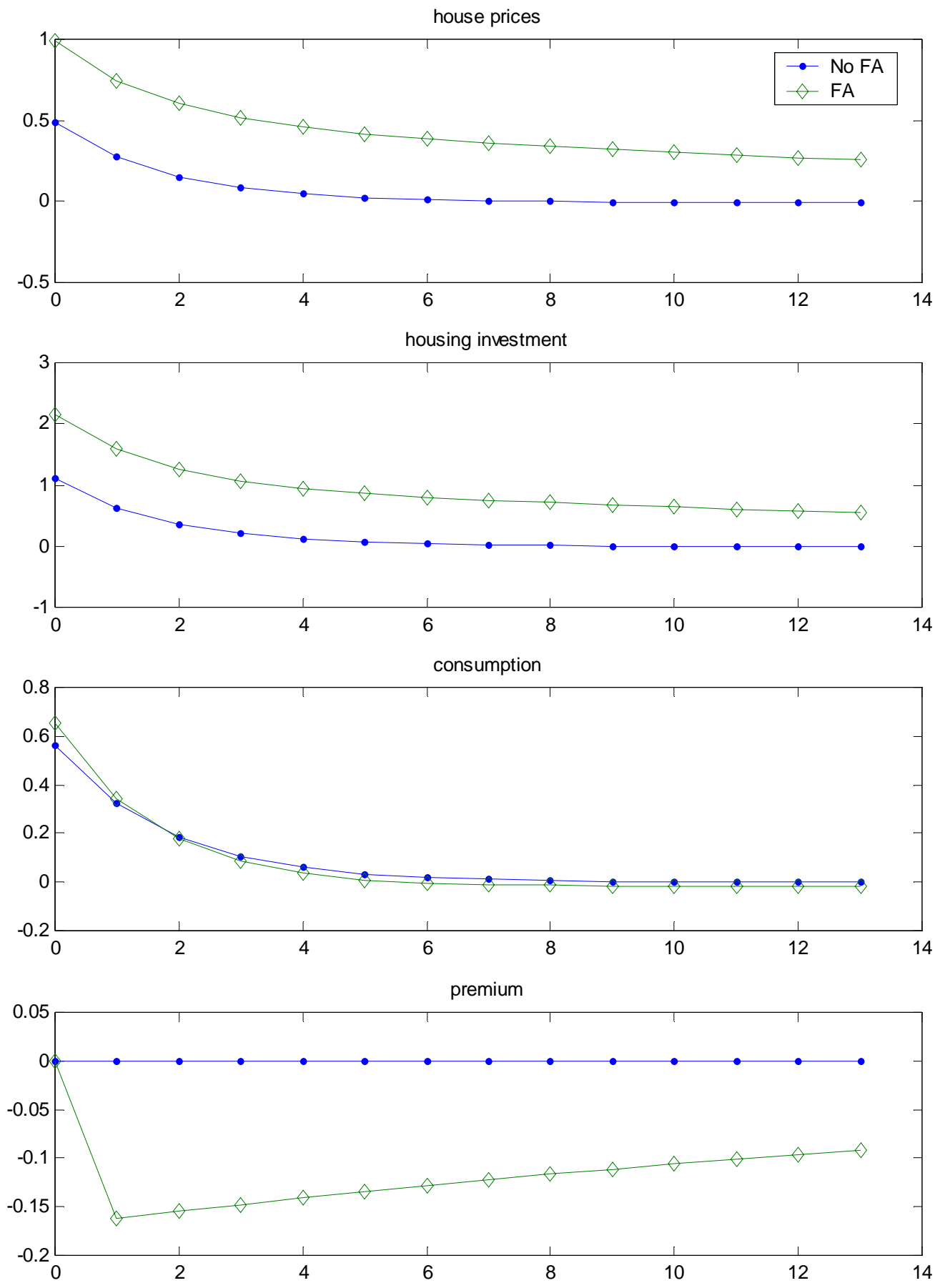
99 basis points to 45 basis points for house prices). Its effect on consumption is to heighten the response (from 66 basis points to 75 basis points). The intuition is as follows: following the monetary policy shock, households respond to the unexpected increase in house prices. When transaction costs are lower, they use more of the increased housing equity to finance consumption. The balance sheet improvement is therefore smaller and shorter-lasting than it would otherwise have been, and this dampens the positive response of housing investment and house prices. Table C summarises these findings.

Table C: Model responses under different assumptions about the financial accelerator

\begin{tabular}{|c|c|c|c|c|}
\hline & Peak response of: & $\widehat{C}$ & $\widehat{q}$ & $\widehat{I}$ \\
\hline without financial accelerator & & 0.56 & 0.48 & 1.11 \\
\hline before deregulation & & 0.66 & 0.99 & 2.14 \\
\hline after deregulation & & 0.75 & 0.45 & 1.10 \\
\hline
\end{tabular}

Based on our choice of parameters, the quantitative impact of deregulation on consumption is therefore to increase the peak response to monetary policy shocks by $14 \%$. The peak house price response falls by about 55\%, and the peak housing investment response falls by $49 \%$. A key parameter driving these results is the elasticity of the transfer with respect to housing equity. Although this parameter can be estimated from data as the elasticity of MEW with respect to housing equity, there are many uncertainties surrounding this estimate. MEW is a flow, which has historically been positive as well as negative. To estimate the elasticity of this flow over short subsamples requires taking a stand on the appropriate 'average MEW', as well as the appropriate sub-sample period. Although we characterise our experiment as comparing 'before deregulation' with 'after deregulation', in reality there are probably three sub-periods in the data, roughly corresponding to a decade each. From 1970-79 could be characterised as before deregulation. From 1980-89 is a period of gradual deregulation. The period 1990-2001 could be characterised as after deregulation. Estimates of the elasticity of MEW with respect to housing equity are highly sensitive to the precise sub-period chosen as some of the sub-period averages of MEW are close to zero. And in the early period 1970-79 the relationship between MEW and net housing equity is not statistically significant. To check the robustness of our approach, we therefore also explore an alternative calibration strategy for the elasticity parameter. Rather than estimating it directly, we calibrate it to match the data covariance between consumption and MEW. The data covariance is 0.0050 for the period $1970-79,0.0083$ for the period $1980-89$ and 0.035 for the period $1990-2001$. To match these covariances in the model, we need to set the elasticity parameter at 1.6, 2.4 and 42 respectively. This is very much in the same range as our estimates of 3 and 30 based on the direct 
Chart 5: Responses to a monetary policy shock: before and after deregulation
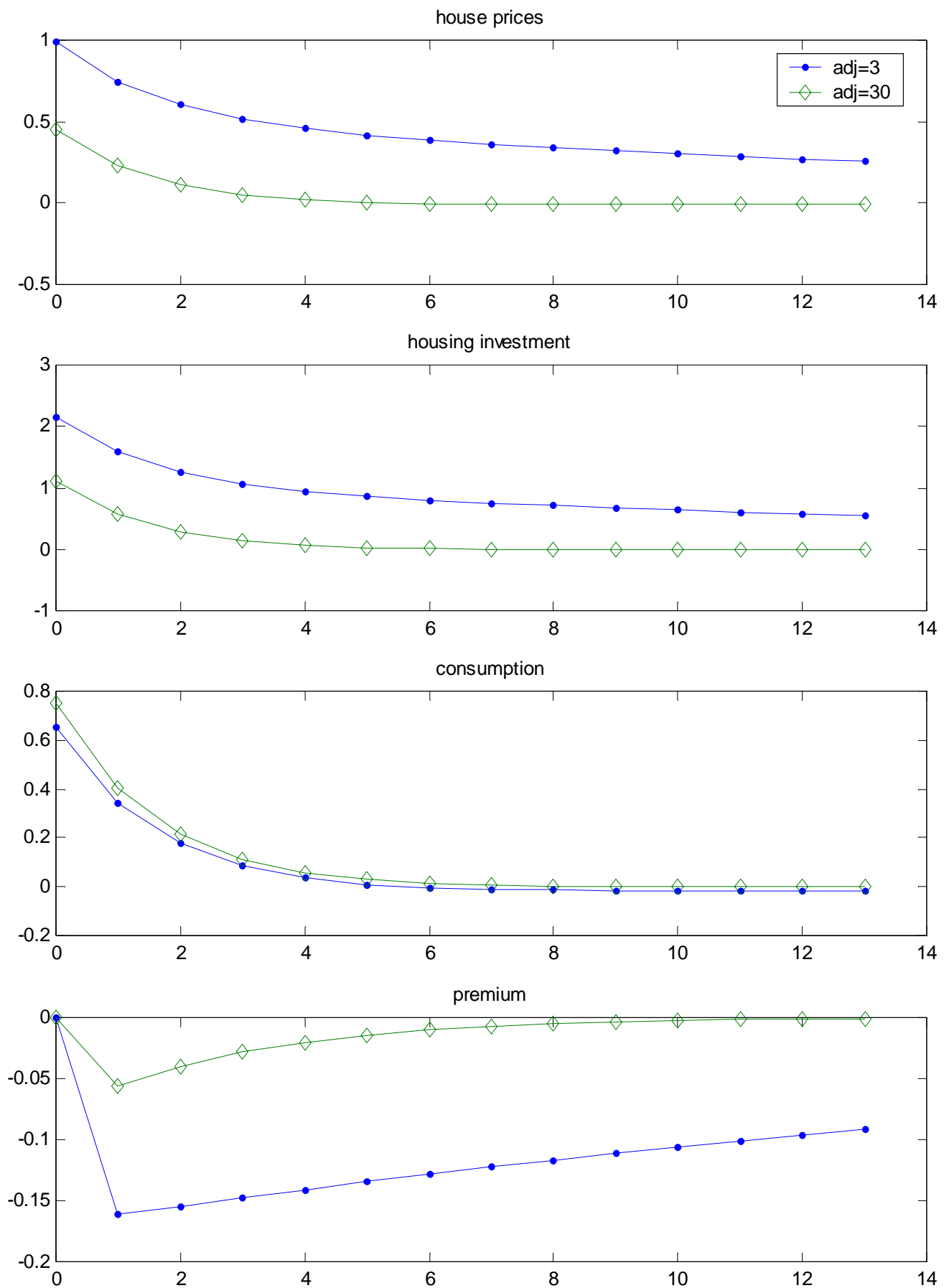
estimation approach. If anything, our direct estimation approach perhaps underestimated the difference between the pre and post-deregulation regimes. ${ }^{(20)}$

It could also be argued that certain types of structural change in financial markets that accompanied deregulation should change the deep parameters of the financial accelerator mechanism, which we have kept constant in our experiments. The most likely change is that the degree to which uncertainty about individual borrower quality may be reduced a result of improved ex ante monitoring techniques of potential borrowers. This in turn would increase the steady-state leverage ratio. But as shown by Hall and Vila Wetherilt (2002), if increases in the steady-state ratio are due to lower uncertainty, they would be accompanied by a lower steady-state external finance premium and a lower elasticity of the external finance premium with respect to leverage. Higher leverage would work to increase amplification, but a lower finance premium and a lower elasticity would partly offset this. Overall, Hall and Vila Wetherilt (2002) show that amplification would still increase, but only moderately. ${ }^{(21)}$ What would be the impact for our model? Higher amplification after the structural change would act as a scaling factor for all of the model responses: relative to our 'after deregulation scenario', consumption and house price responses would be slightly higher. Our conclusions about the relative movements of consumption (more responsive to monetary policy shocks) would still be valid. Our conclusion about house prices (less responsive to monetary policy shocks) would still be valid if the moderate amplification effect from higher leverage is outweighed by the strong dampening effect of better access to borrowing for consumption.

\section{Conclusion}

In this paper we have presented a general equilibrium model, based on the financial accelerator model of Bernanke, Gertler and Gilchrist (1999) that describes how this credit channel may form part of the monetary transmission mechanism. The model focuses on the macroeconomic effects of imperfections in credit markets. Such imperfections generate premia on the external cost of

(20) Another robustness check we performed was to investigate the impact of the curvature of the utility function. Our baseline model has log utility, implying an intertemporal rate of substitution of 1 , which is on the high side compared to direct estimates from consumption data (Hall (1988)). A lower intertemporal rate of substitution clearly scales the consumption response to monetary policy shocks down, but increases the difference between the pre and post-deregulation regimes.

(21) Hall and Vila Wetherilt (2002) conclude that the amplification effect is moderate even though the uncertainty parameter has halved. The reduction in uncertainty we consider here, due to improved monitoring technology in retail financial markets, is unlikely to have been that large. 
raising funds, which in turn affect borrowing decisions. Within this framework, endogenous developments in credit markets—-such as variations in net worth or collateral—work to amplify and propagate shocks to the macroeconomy. A positive shock to economic activity causes a rise in housing demand, which leads to a rise in house prices and so an increase in homeowners' net worth. This decreases the external finance premium, which leads to a further rise in housing demand and also spills over into consumption demand.

We also consider the implications for monetary policy of structural changes in the United Kingdom's retail financial markets: following deregulation in the mortgage market, it became easier and cheaper for consumers to borrow against housing collateral to finance consumption. We show that cheaper access to home equity means that, for a given house price increase, more borrowing will be devoted to consumption relative to housing investment. The response of consumption to an unanticipated change in interest rates will therefore be larger, and the response of house prices and housing investment will be smaller. In other words, whether the financial accelerator has most of its effect on house prices or consumption depends on the degree of deregulation: in a highly deregulated mortgage market, the effect on house prices will be muted, but the effect on consumption will be amplified. This has important implications for the information content of house prices, because it implies that, even for similar economic shocks, the relationship between house prices and consumption is changing over time. 


\section{Appendix 1: Complete log-linearised model}

We log-linearise the model around the steady state with constant prices. In the steady state, the leverage ratio of the household sector is assumed to be $\phi$. Furthermore, we normalise the adjustment cost function of housing investment such that the relative price of houses in the steady state is unity. Below, variables with hats denote per cent deviations from the steady state, and variables without time subscripts denote the steady-state values of those.

Aggregate demand

$$
\begin{gathered}
\hat{Y}_{t}=\frac{c}{Y} \hat{c}_{t}+\frac{I}{Y} \hat{I}_{t}+\frac{G}{Y} \hat{G}_{t} \\
\hat{C}_{t}=n_{p} \hat{C}_{t}^{p}+\left(1-n_{p}\right) \hat{C}_{t}^{r} \\
\hat{C}_{t}^{p}=E_{t} \hat{C}_{t+1}^{p}-\hat{R}_{t} \\
\hat{C}_{t}^{r}=c_{w} \hat{w}_{t}+\left(1-c_{w}\right) \hat{D}_{t} \\
\hat{c}_{t}=\hat{C}_{t}-\eta \hat{X}_{c, t} \\
\hat{h}_{t}=\hat{C}_{t}-\eta \hat{X}_{h, t} \\
\hat{X}_{c, t}=-\frac{1-\gamma}{\gamma} \frac{X_{h}^{1-\eta}}{X_{c}^{1-\eta}} \hat{X}_{h, t} \\
E_{t} \hat{R}_{h, t+1}=\hat{R}_{t+1}-v\left\{\hat{N}_{t+1}-\left(\hat{q}_{t}-\hat{h}_{t+1}\right)\right\} \\
\hat{R}_{h, t+1}=(1-\mu) \hat{X}_{h, t}+\mu \hat{q}_{t+1}-\hat{q}_{t} \\
\hat{q}_{t}=\psi\left(\hat{I}_{t}-\hat{h}_{t}\right)+\hat{X}_{c, t}
\end{gathered}
$$

Aggregate supply

$$
\begin{gathered}
\hat{Y}_{t}=\hat{A}_{t}+(1-\alpha) \hat{L}_{t} \\
m \hat{c}_{t}=\hat{w}_{t}+\frac{1}{1-\alpha} \hat{Y}_{t}-\frac{1}{1-\alpha} \hat{A}_{t}+\hat{X}_{c, t} \\
\hat{w}_{t}=\hat{C}_{t}+\xi \hat{L}_{t} \\
\hat{\pi}_{c, t}=\kappa_{1} m \hat{c}_{t}+\beta E_{t} \hat{\pi}_{c, t+1}
\end{gathered}
$$


Evolution of state variables

$$
\begin{gathered}
\hat{h}_{t+1}=\delta \hat{I}_{t}+(1-\delta) \hat{h}_{t} \\
\hat{N}_{t+1}=R_{h} \hat{V}_{t}-\left(R_{h}-1\right) \hat{D}_{t} \\
=R_{h}\left[(1+\phi) \hat{R}_{h, t}-\phi v\left(\hat{q}_{t-1}+\hat{h}_{t}\right)+(1+\phi v) \hat{N}_{t}-\phi \hat{R}_{t-1}\right]-\left(R_{h}-1\right) \hat{D}_{t} \\
\hat{D}_{t}=s\left(\hat{N}_{t+1}-\left(\hat{q}_{t}-\hat{h}_{t+1}\right)\right)
\end{gathered}
$$

Monetary policy and exogenous shocks

$$
\hat{R}_{t}^{n}=\rho_{R} \hat{R}_{t-1}^{n}+r_{\pi} \hat{\pi}_{t}+\varepsilon_{R, t}
$$

where the relationship between nominal and real rates are given by

$$
\begin{gathered}
R_{t+1}^{n}=R_{t+1}+E_{t} \pi_{t+1} \\
\hat{G}_{t}=\rho_{G} \hat{G}_{t-1}+\varepsilon_{G, t} \\
\hat{A}_{t}=\rho_{A} \hat{A}_{t-1}+\varepsilon_{A, t}
\end{gathered}
$$

with

$$
\begin{gathered}
n_{p} \equiv n \frac{C^{p}}{C}, \quad c_{w} \equiv \frac{w L^{r}}{C^{w}} \\
v \equiv \frac{f^{\prime}(\phi)}{f(\phi)} \phi, \quad \mu \equiv \frac{X^{h}}{X_{h}-(1-\delta)} \\
s \equiv \frac{\chi^{\prime}(\phi)}{\chi(\phi)} \phi, \quad \psi \equiv \frac{\left(\Phi(I / h)^{-1}\right)^{\prime}}{\left(\Phi(I / h)^{-1}\right)^{\prime \prime}} \\
\kappa_{1} \equiv\left(\frac{1-\theta}{\theta}\right)(1-\theta \beta)
\end{gathered}
$$

Equation (A-1) is resource constraint. ${ }^{(22)}$ Equation (A-2) defines aggregate consumption, while equations (A-3) and (A-4) represent consumption of each of the PIH and ROT consumers. Equations (A-5) and (A-6) are the demand for consumption goods and housing services, respectively. Equation (A-7) is an identity. Equations (A-8), (A-9), and (A-10) characterise housing investment demand. They are log-linearised versions of (3), (2), and (16), respectively. Equation (A-8) represents the relationship between the external finance premium and household 
net worth relative to gross value of housing. A rise in this ratio reduces the cost of external finance. Equation (A-9) defines ex post return from housing investment.

Equation (A-11) is the log-linearised Cobb-Douglass production function, under the assumption that capital is fixed. Equations (A-12) and (A-13) jointly characterise labour market equilibrium. Equation (A-14) is a variant of the New Keynesian Phillips curve.

Equation (A-15) is the log-linearised version of the conventional transition equation of housing capital. The evolution of net worth, (A-16), depends on the net return from housing investment minus dividend payments. This is obtained from log-linearised equations of (1), (4), and (5). The dividend rule is given by (A-17), which is the log-linearised version of (6). Dividends are assumed to be increasing in the ratio of net worth to the gross value of housing.

Equation (A-18) is the monetary policy rule. Following a large literature, we assume the short-term nominal interest rate is the policy instrument. This does not imply that such a rule is an accurate description of monetary policy in the United Kingdom, but it offers a convenient way in which to capture an active monetary policy. Finally, equations (A-20) and (A-19) represent the exogenous processes of technology and government expenditures. 


\section{Appendix 2: Parameterisation}

We have aimed to keep the parameterisation of the model fairly standard. The discount rate $\beta$ equals 0.99 . The steady state quarterly real interest rate is therefore $1 / \beta$ or 1.01 , which implies an annual real interest rate of $4.04 \%$. The elasticity of substitution $\eta$ between consumption and housing services is equal to 1 . Together with the parameter $\gamma$ in the CES consumption aggregator, this pins down the steady-state ratio of imputed rent to total consumption at about $12 \%$, which is consistent with aggregate data. ${ }^{(23)}$ The depreciation rate of housing is set at an annual rate of $2 \%$. The elasticity of the price of capital with respect to the investment capital ratio, $\psi$, is set to 0.5 . BGG suggest that a reasonable range for this parameter is $0-0.5$. The disutility of labour parameter, $\varepsilon$, is set to 1 . The capital share in aggregate production, $\alpha$, is set to 0.33 . Following BGG, we set labour supply elasticity to 3 .

The parameter $\theta$ governs the stickiness of prices of consumption goods. We set it at 0.75 , which implies that the average period between price adjustments is four quarters. There are three shock processes in our model: productivity shocks, demand shocks and monetary policy shocks. Productivity and demand shocks are assumed to be autocorrelated with autoregressive parameters $\rho_{A}=0.95$ and $\rho_{G}=0.9$ respectively. The monetary authorities are assumed to follow a smoothed feedback rule with autoregressive parameter $\rho_{R}=0.9$ and a coefficient on lagged inflation of 0.2 , implying a long-run response to inflation of 2 .

In order to evaluate model covariance of the variables, we also need to specify variances of the shocks. We specify all shocks to have a variance of $(0.01)^{2}$ which is well within the range used in the literature (eg Batini, Harrison and Millard (2001), Nelson (2000) and Nelson and Neiss (2001)).

The parameters governing the financial accelerator are similar to those used in BGG. We assume that underlying these parameters is a model of costly state verification, for example the one derived explicitly in BGG. The steady state annual external finance premium is 200 basis points,

(23) We experimented with a lower value for $\eta$, which would imply some degree of complementarity between housing and consumption. However, as long as $\gamma$ is increased to correct for obtaining reasonable share of imputed rents, there is no significant effect in the model simulations from having changed $\eta$. 
and the ratio of net worth to capital is 0.7 , which is the average historical leverage ratio of UK households. This may seem low at first sight, since households are often thought of as highly leveraged. While it is true that first-time buyers only put down deposits of 0.2 or less, the household sector in aggregate has a much higher net worth ratio reflecting the fact that mature mortgages have been partly paid off and that many households actually own their houses outright. The only thing about these parameters that is important for our results is that the cost of external finance is some upward sloping function of leverage. The individual parameters underlying the financial accelerator mechanism simply act as scaling factors on the overall acceleration. We set the elasticity of the external finance premium with respect to leverage equal to 0.1 - higher than the BGG value of 0.05 - to match the relative responses of consumption and housing investment once the financial accelerator is switched on. The adjustment factor $s$ on the dividend rule is set at 3. This is the estimated average elasticity of mortgage equity withdrawal with respect to the net worth ratio. In other words, if the net worth of the aggregate UK household sector rises by $1 \%$, the amount of equity withdrawn will increase by $3 \%$. In our structural change experiment, we vary this baseline parameter as described in Section 6.2. 


\section{Appendix 3: Data sources}

For the estimation in Section 2 and the charts, we used the following series. Item codes from the National Statistics office are provided in parentheses where applicable.

Real house prices: DETR house price index deflated by the GDP deflator (YBGB). Real consumption (ABJR). Real durables consumption (AEIW). Mortgage Equity Withdrawal: nominal MEW (Bank of England estimate). Net housing equity: nominal housing stock (National Statistics estimate) minus total secured borrowing by households (Bank of England) divided by the nominal housing stock. Real housing investment (DFEA). Household disposable income (RPQK). Real money balances: M4 (Bank of England) deflated by the GDP deflator. 


\section{References}

Aoki, K, Proudman, J and Vlieghe, G (2001), 'Why house prices matter', Bank of England Quarterly Bulletin, Winter, pages 460-68.

Aoki, K, Proudman, J and Vlieghe, G (2002), 'Houses as collateral: has the link between house prices and consumption in the U.K. changed', Federal Reserve Bank of New York Economic Policy Review, Vol. 8(1), pages 163-78.

Bank of England (2001), Minutes of the Monetary Policy Committee meetings, April.

Batini, N, Harrison, R and Millard, S (2001), 'Monetary policy rules for an open economy', Bank of England Working Paper no. 149.

Bayoumi, T (1993), 'Financial deregulation and consumption in the United Kingdom', Review of Economics and Statistics, pages 536-39.

Bernanke, B and Gertler, M (1989), 'Agency costs, net worth, and business fluctuations', American Economic Review, Vol. 79, pages 12-31.

Bernanke, B and Gertler, M (1995), 'Inside the black box: the credit channel of monetary policy transmission', Journal of Economic Perspectives, Vol. 9(4), pages 27-48.

Bernanke, B and Gertler, M (2000), 'Monetary policy and asset price volatility', NBER Working Paper Series, No. 7559.

Bernanke, B, Gertler, $M$ and Gilchrist, $S$ (1999), 'The financial accelerator in a quantitative business cycle framework', Handbook of macroeconomics (North Holland).

Calvo, G (1983), 'Staggered prices in a utility-maximizing framework', Journal of Monetary Economics, Vol. 12, pages 383-98.

Campbell, J and Mankiw, G (1989), 'Consumption, income, and interest rates: reinterpreting the time series evidence’, NBER Macroeconomics Annual 1989.

Carroll, C D (1997), 'Buffer stock saving and the permanent income hypothesis', Quarterly Journal of Economics, Vol. 112(1), pages 1-56.

Carroll, C D and Dunn, W D (1997), 'Unemployment expectations, jumping (s,s) triggers, and household balance sheets', NBER Macroeconomics Annual 1997.

Case, K, Quigley, J and Shiller, R (2001), 'Comparing wealth effects: the stock market versus the housing market', NBER Working Paper Series, No. 8606.

Christiano, L J, Eichenbaum, M and Evans, C (1996), 'The effects of monetary policy shocks: evidence from the flow of funds', Review of Economics and Statistics, Vol. 78(1), pages 16-34. 
Deaton, A (1991), ‘Saving and liquidity constraints', Econometrica, Vol. 59, pages 1,121-42.

Deaton, A (1992), Understanding consumption, Oxford: Clarendon Press.

Fernandez-Corugedo, E (2000), 'Soft liquidity constraints and precautionary savings', Bank of England Working Paper no. 158.

Gertler, M (1999), 'Government debt and social security in a life-cycle economy', Carnegie-Rochester Conference Series on Public Policy, Vol. 50, pages 61-110.

Gertler, M and Gilchrist, S (2000), 'Hump-output dynamics in a rational expectations framework: the role of investment delays', mimeo.

Gertler, M, Gilchrist, S and Natalucci, F M (2000), 'External constraints on monetary policy and the financial accelerator', Working Paper, New York University.

Goodhart, C A E (1989), Money, information and uncertainty, London: MacMillan Press Ltd.

Gourinchas, P O (2000), 'Precautionary savings, life cycle, and macroeconomics', Working Paper, Princeton University.

Gourinchas, P O and Parker, J (1999), 'Consumption over the life cycle', Working Paper, Princeton University.

Greenspan, A (2001), Monetary Policy Report to Congress, Board of Governors of the Federal Reserve System, 18 July.

Hall, R E (1988), 'Intertemporal substitution in consumption', Journal of Political Economy, Vol. 96(2), pages 339-57.

Hall, S (2001), 'Financial effects on corporate investment in UK business cycles', Bank of England Quarterly Bulletin, Winter, pages 449-59.

Hall, S and Vila Wetherilt, A (2002), 'The role of corporate balance sheets and bank lending policies in a financial accelerator framework', Bank of England Working Paper no. 166.

Hubbard, G (1998), 'Capital-market imperfections and investment', Journal of Economic Literature, Vol. 36, pages 193-225.

Iacoviello, M (2002), 'House prices, borrowing constraints and monetary policy in the business cycle', unpublished, London School of Economics.

Iacoviello, $M$ and Minetti, $\mathbf{R}$ (2000), 'The credit channel of monetary policy and the housing market: international empirical evidence', Bank of Finland Discussion Paper no. 14.

Jappelli, T and Pagano, M (1989), 'Consumption and capital market imperfections: an international comparison', American Economic Review, Vol. 79, pages 1,088-105.

Lamont, $O$ and Stein, J (1999), 'Leverage and house-price dynamics in US cities', RAND Journal of Economics, Vol. 30(3), pages 498-514. 
Ludvigson, S (1999), 'Consumption and credit: a model of time-varying liquidity constraints', Review of Economics and Statistics, Vol. 81(3), pages 434-47.

McCallum, B and Nelson, E (1999), 'Performance of operational policy rules in an estimated semi classical structural model', in Taylor, J (ed), Monetary policy rules, University of Chicago Press.

Moneyfacts (2002), Moneyfacts Group, April issue.

Muellbauer, J and Murphy, A (1993), 'Income expectations, wealth and demography in the aggregate UK consumption function', mimeo, University of Oxford.

Muellbauer, J and Murphy, A (1995), 'Explaining regional consumption in the UK', mimeo, University of Oxford.

Muellbauer, J and Murphy, A (1997), 'Booms and busts in the UK housing market', Economic Journal, Vol. 107, pages 1,701-27.

Nelson, E (2000), 'UK monetary policy 1972-97: a guide using Taylor rules', Bank of England Working Paper no. 120.

Nelson, E and Neiss, K (2001), 'The real interest rate gap as an inflation indicator', Bank of England Working Paper no. 130.

Pratt, M J (1980), 'Building societies: an econometric model', Bank of England Discussion Paper no. 11.

Rotemberg, J and Woodford, M (1999), 'Interest-rate rules in an estimated sticky-price model', in Taylor, J (ed), Monetary policy rules, University of Chicago Press.

Rudebusch, G D and Svensson, L E O (1999), 'Policy rules for inflation targeting', in Taylor, J (ed), Monetary policy rules, University of Chicago Press.

Sims, C A (1992), 'Interpreting the macroeconomic time series facts: the effect of monetary policy', European Economic Review, Vol. 36(5), pages 975-1,000.

Taylor, J (1993), 'Discretion versus policy rules in practice', Carnegie-Rochester Conference Series on Public Policy, Vol. 39, pages 195-214.

Wilcox, J B (1985), 'A model of the building society sector', Bank of England Discussion Paper no. 23 .

Woodford, M (1996), 'Control of public debt: a requirement for price stability?', NBER Working Paper Series, No. 5684. 